\title{
Molecular Docking Study of Flavonoid Compounds in The Guava Leaves (Psidium Guajava L.) Which Has Potential as Anti- Inflammatory COX-2 Inhibitors
}

\author{
Dina Ahsana ${ }^{a, 1}$, Andika ${ }^{a}{ }^{*}$, Siti Nashihah ${ }^{a, 3}$ \\ ${ }^{a}$ Faculty of Pharmacy, University of Muhammadiyah Banjarmasin, 70581, South Kalimantan, Indonesia \\ 1 andika@umbjm.ac.id* \\ *korespondensi penulis
}

\begin{tabular}{l}
\hline INFO ARTIKEL \\
\hline Diterima : \\
II-05-202I \\
Direvisi : \\
O5-07-202I \\
Disetujui : \\
O6-07-202I \\
\hline
\end{tabular}

\section{Kata kunci: \\ Penambatan Molekuler; \\ Autodock4;}

Psidium guajava L;

Antiinflamasi Inhibitor ;

COX-2;

Flavonoid.

\section{ABSTRAK}

Inflamasi yang bersifat progresif cenderung akan merusak dan menimbulkan beberapa permasalahan dalam tubuh. Enzim COX-2 merupakan salah satu mediator yang berkontribusi besar dalam terjadinya inflamasi progresif. Penelitian secara eksperimental daun jambu biji (Psidium guajava L.) terbukti memiliki aktivitas anti-inflamasi diduga karena banyak terkandung senyawa flavonoid, namun masih belum ada penelitian aktivitasnya terhadap penghambatan COX-2 selektif. Tujuan dari penelitian ini yaitu untuk mengetahui potensi senyawa flavonoid memiliki aktivitas anti-inflamasi penghambat COX-2 selektif menggunakan uji penambatan molekul. Metode: 3I senyawa flavonoid daun jambu biji didapat dari studi literatur beberapa penelitian in-vitro dan kode protein ID: 6COX yang digunakan pada penelitian penambatan molekular ini dilakukan energi minimisasi terlebih dahulu. Selanjutnya digunakan software docking Autodock4 dengan metode semiflexible dan Lamarckian Genetic Algorithm (LGA). Semua senyawa flavonoid juga dilakukan prediksi Absorpsi, Distribusi, Metabolisme, Ekskresi, Toksisitas (ADMET). Hasil: secara keseluruhan diperoleh semua 3I senyawa uji flavonoid daun jambu biji berpotensi sebagai inhibitor COX-2 dan beberapa senyawa uji diantaranya memiliki nilai docking $\Delta \mathrm{G}$ terbaik yang berasal dari Epicatechin-3O-Gallate sebesar -9,3 I kcal/mol, disusul oleh Gallocatechin sebesar -8,97 $\mathrm{kcal} / \mathrm{mol}$ serta Tamarixetin $-8,83 \mathrm{kcal} / \mathrm{mol}$. Residu asam amino SER 353, TYR 385, SER 530, GLN 192 dan ARG I20 juga banyak berkontibusi dalam terbentuknya ikatan hidrogen. Kesimpulan: Epicatechin-3-O-Gallate merupakan senyawa uji yang memiliki potensi besar sebagai anti-inflamasi inhibitor COX-2 selektif karena memiliki kekuatan dan kestabilan ikatan yang tinggi dengan energi docking terendah saat ditambatkan pada protein target.

\section{Keyword:}

Molecular Docking;

Autodock4;

Psidium guajava L;

Inhibitor Anti-inflammatory;

COX-2;

Flavonoids.

\section{ABSTRACT}

Progressive inflammation tends to damage and cause several problems in the body. The COX-2 enzyme is one of the mediators that have a significant contribution to progressive inflammation. Experimental study, guava leaves (Psidium guajava L.), have anti-inflammatory activity, presumably because they contain many flavonoid compounds. However, the lack of those research on their action against selective COX-2 inhibition. The purpose of this study is to determine the potential for flavonoid compounds to have anti-inflammatory activity of selective COX-2 inhibitors using molecular docking. Method: 3 I flavonoids compound of guava leaves found on some literature studies of a systematic literature review and protein code ID: 6COX used on this molecular docking study by applying minimization energy at first. Next, using Autodock 4 docking software with semi-flexible and Lamarckian Genetic Algorithm (LGA) methods. All flavonoid compounds also used screening Absorption, Distribution, Metabolism, Excretion, Toxicity (ADMET) prediction. Results: Overall results obtained that all $3 \mathrm{I}$ compounds of guava leaf flavonoids can potentially be COX-2 inhibitors. One of them has the best docking value with $\Delta \mathrm{G}$ from Epicatechin-3-O-Gallate of $-9.3 \mathrm{I} \mathrm{kcal} / \mathrm{mol}$ is high than the 
Gallocatechin of $-8.97 \mathrm{kcal} / \mathrm{mol}$ and $-8.83 \mathrm{kcal} / \mathrm{mol}$ Tamarixetin. The amino acid residues SER 353, TYR 385, SER 530, GLN I92, and ARG I20 contributed significantly to form hydrogen bonds. Conclusions: Epicatechin-3O-Gallate has significant potential as an anti-inflammatory selective COX-2 inhibitor because it has high bond strength and stability with the lowest energy binding when attached to the target protein.

This is an open access article under the CC-BY-SA license.

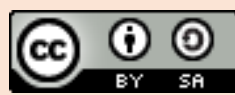

\section{Introduction}

Inflammation is a biological body response, usually a protective physiological response to tissue injury caused by physical trauma, damaging chemical agents, and infection with microbiological agents (Chen et al., 2018). However, in progressive pathological conditions, where antigens dominate the situation, the inflammation can damage cells, tissues, or organs (Nurtamin, Sudayasa, and Tien 2018). The incidence of inflammation is dominated by their mediators of pro-inflammatory prostaglandininduced cyclooxygenase enzyme, and other research shows the inhibition of Cyclooxygenase-2 (COX-2) can reduce $75 \%$ of the production prostaglandins. In contrast, Cyclooxygenase-I (COX-I) inhibition only decreases in $25 \%$ of total prostaglandins in rats (Ricciotti and Fitzgerald 20II). From these data, it can be seen that the enzyme COX-2 mainly releases the prostaglandins that cause inflammation compared to COX-I. Additionally, the high expression of COX-2 has played a major role in the development of serious diseases such as cancer (Desai, Prickril, and Rasooly 2018), Alzheimer (Guan and Wang 2019), diabetes (Fujita et al. 2007), osteoarthritis, and rheumatoid arthritis (Curtis et al. 2019). On the other side, the inflammatory medication that specifically inhibits COX-2 is limited, and celecoxib is the drug most frequently used. Therefore it is necessary to make new drug discovery as a drug candidate.

Guava leaves (Psidium guajava L.) are known to have anti-inflammatory activity. Research from Choi et al. (2008) showed that ethanol extract from guava leaves fermentation showed an inhibitory effect of inducible nitric oxide synthase (iNOS), COX-2, and NF $\mathrm{k} \beta$ activation has induced by lipopolysaccharide on RAW 264,7 cells. Researchers assume that guava leaves contain lots of flavonoids that might give these anti-inflammatory effects. The anti-inflammatory activity of these flavonoids was also supported by in silico studies on the flavonoid binding model with COX-2 exploring that several flavonols and flavones containing 2,3-double bonds may act as preferential inhibitors COX-2 (D'mello et al. 20II). Recent research conducted by Sen et al. (2015) shows that the flavonoid fraction of guava leaf extract is effective in inhibiting Lipopolysaccharide (LPS) induced production of Nitric Oxide (NO) and Prostaglandin E2 (PGE2). Other results using either RT-PCR or western blot also showed inducible iNOS and COX2 inhibiting activity. However, the researchers' Sen et al. (20I5) weakness is that there is no screening of guava leaves' flavonoid contents, so further research is needed.

The method used to identify potential antiinflammatory activity in plant compounds, especially guava leaves, is molecular docking. Molecular docking is a molecular modeling technique used to predict how proteins (enzymes) interact with small molecules (ligands) (Roy, Kar, and Das 2015). Molecular docking in drug development is included in the Structure-Based Drug Design (SBDD) group by utilizing information from the target protein structure to find the protein's active site that binds to the drug compound. The prediction of the best active site is expected to create a bond between the compound and the target protein to form expected biological activity (Pranowo 2009; Roy et al. 2015).

\section{Method}

\section{Equipment and Materials}

The hardware used in this molecular docking study was the Acer Aspire A5I4-53G VGA laptop with a specification of CoreTM i5-I035GI

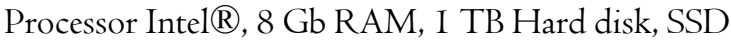
$5 \mathrm{I} 2 \mathrm{~Gb}$, and Microsoft Windows $\mathrm{IO}$ as an operating system. The docking software we are used was Autodock 4.2.6, energy minimization of ligandprotein using Avogadro and Swiss PDB Viewer software. Discovery Studio Visualizer and PyMOL for visualizing protein-ligand interactions. pkCSM web tools for ADMET prediction. 


\section{Protein-Ligand Preparation}

Protein target complexed with selective inhibitor COX-2 was downloaded in RCSB PDB web in code ID: 6COX. All water molecule and non-standard residues were removed from the protein structure, adding all hydrogen (Yusuf et al. 2018) and separating chain A protein with ligand native's SC558 using Autodock software (Sohilait, Harno Dwi Pranowo, and Winarto Haryadi 2017). Then we downloaded the PubChem website for celecoxib, and 3 I flavonoid compounds of guava leaves are from Anand et al., 2016; Barbalho et al., 2012; Habtemariam, 2019; Jiang et al. 2020; Thome, Sudiana, and Bakar 2019 article scientific is as ligands. Those five-article scientific had been proven by an experimental study in a systematic literature review. In this study, all ligands (3I flavonoid compounds, celecoxib, and ligand native SC-558) were optimized by energy minimization using Avogadro software with MMFF94 force field parameters (Hussein and Elkhair 202I). Swiss PDB Viewer software with GROMOS96 force field for protein minimization (Satyanarayana et al. 2018).

\section{Protein-Ligand Docking}

Molecular docking was performed using the Autodock Tools (Autodock4 \& Autogrid4) programs. Kollman and Gastaiger charges were added automatically on protein and ligand after identifying ligand torsions (Yusuf et al., 2018). Docking validation steps start from setting grid box active site of protein, grid box dimension size was $40 \times 40 \times$ 40 and coordinate's $(X=22.903$ points, $Y=$ $23.48 \mathrm{I}$ points, $Z=46.936$ points) with a space of $0.375 \AA$ A. Flexible ligand and rigid macromolecule were setting for protein target because this method used semi-flexible docking. We did 100 search conformation per compound on Autodock 4.2.6 used the Lamarckian Genetic Algorithm with I50 population of Size and 2.500.000 maximum number of evals (Fuhrmann et al. 2010). The best confirmation as a re-docking ligand was comparing for validation. Methods docking validation were valid if the Root Mean Square Deviation (RMSD) score of re-docking and co-crystal ligand was lower than $2 \AA$ (Wati, Widodo, and Herowati 2020). The visualization analysis of protein-ligand 2Dimensional interaction was view by BIOVIA Discovery Studio Visualizer and 3-Dimensional using PyMol software (Harisna et al. 202I).

\section{ADMET Prediction}

The Absorption, Distribution, Metabolism, Excretion, and Toxicity (ADMET) prediction are the crucial technique employed in silico pharmacokinetic parameters profile of chemical compounds that may affect their pharmacodynamic activities (Nisha et al. 2016). There is a lot of online tools and offline software to predict ADMET. In this study, we have used Predicting Small-Molecule Pharmacokinetic Properties Using Graph-Based Signatures (pcKSM) online web tools to predict ADMET quickly and have a highly accurate result (D. E. V. Pires, Blundell, and Ascher 2015). Each compound model will be predicted on ADMET properties tested on hundreds or thousands of drugs before getting accurate prediction data. This prediction starts by preparing every of the best conformation of 33 ligands screened for ADMET by changing the format to SMILES and then uploading it in pcKSM online web tools.

\section{Results and Discussion}

Molecular docking is an in silico technique that can predict the interaction between small ligands (compounds) and target proteins in a stable binding area. This interaction will show how strong affinity (the ability of a compound to bind to a protein pocket) is indicated by the binding energy (Iheagwam et al., 2019). The success assessment of the molecular docking results was analyzed based on the RMSD docking validation, the Gibbs Binding Energy $(\Delta G)$, and the Inhibition Constant (IC).

\section{Docking Validation}

Docking validation was carried out to check the efficiency of the docking method by comparing cocrystal ligands and ligand re-docking. This method procedure was verified effectively using the RMSD parameter with a docking validation value $\leq 2 \AA$ (Kartasasmita, Anugrah, and Tjahjono 2015). Based on this research, the RMSD value of the validation parameter is $I .064 \AA$, indicating that the ligands and receptors docked have valid criteria of the docking method, so the method can determine the other compounds. The RMSD value $\leq 2 \AA$ shows that the native ligand SC-558 position of the co-crystal ligand and re-docking ligand is not too far away, and the conformation is very similar (Adelina 20I4). 


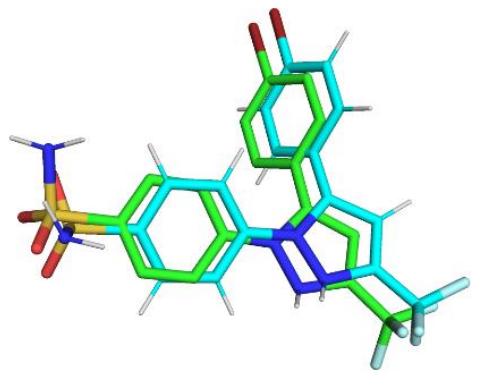

Figure I Overlapping visualization SC-558 native ligand of co-crystal (green-dark blue) and redocking ligand (light blue-dark blue) with $1.064 \AA$ RMSD value

\section{Gibbs Free Energy $(\Delta \mathrm{G})$ and Inhibition Constant (IC)}

The best docking results can be analyzed by comparing the $\Delta \mathrm{G}$ and the IC value. Gibbs binding energy indicated the strength of a ligand-receptor bond (affinity). The lowest Gibbs binding energy value (the value is getting negative) indicates the best ligand and receptor bond stability level. The bonds formed are stronger and have maximum inhibitory activity (Abdillah, Ilmah, and Mahardhika 2017). The IC plays an essential role in evaluating molecular docking because it determines how strong the protein-ligand bond produces inhibitory activity (Kelutur, Mustarichie, and Umar 2020)

Table I Docking result of protein-ligand with Autodock4

\begin{tabular}{|c|c|c|c|}
\hline No & Chemical compounds & Gibbs free energy $(\Delta G)$ & Inhibition Constant (IC) \\
\hline $\mathrm{I}$ & SC-558 & - $10.96 \mathrm{kcal} / \mathrm{mol}$ & $9.30 \mathrm{nM}$ (nanomolar) \\
\hline 2 & Celecoxib & - $10.37 \mathrm{kcal} / \mathrm{mol}$ & $24.84 \mathrm{nM}$ (nanomolar) \\
\hline 3 & Epicatechin-3-O-Gallate & $-9.3 \mathrm{I} \mathrm{kcal} / \mathrm{mol}$ & I49.65 nM (nanomolar) \\
\hline 4 & Gallocatechin & $-8.97 \mathrm{kcal} / \mathrm{mol}$ & $266.19 \mathrm{nM}$ (nanomolar) \\
\hline 5 & Tamarixetin & $-8.83 \mathrm{kcal} / \mathrm{mol}$ & 335.7I nM (nanomolar) \\
\hline 6 & Myricetin & $-8.65 \mathrm{kcal} / \mathrm{mol}$ & $458.73 \mathrm{nM}$ (nanomolar) \\
\hline 7 & Leucocyanidin & $-8.45 \mathrm{kcal} / \mathrm{mol}$ & $642.15 \mathrm{nM}$ (nanomolar) \\
\hline 8 & Isorhamnetin & $-8.4 \mathrm{I} \mathrm{kcal} / \mathrm{mol}$ & $680.34 \mathrm{nM}$ (nanomolar) \\
\hline 9 & Cyanidin & - $8.4 \mathrm{I} \mathrm{kcal} / \mathrm{mol}$ & $684.37 \mathrm{nM}$ (nanomolar) \\
\hline 10 & Phlorizin & $-8.40 \mathrm{kcal} / \mathrm{mol}$ & $699.50 \mathrm{nM}$ (nanomolar) \\
\hline II & Guaijaverin & $-8.38 \mathrm{kcal} / \mathrm{mol}$ & $718.67 \mathrm{nM}$ (nanomolar) \\
\hline $\mathrm{I} 2$ & Catechin & $-8.35 \mathrm{kcal} / \mathrm{mol}$ & $753.5 \mathrm{I} \mathrm{nM}$ (nanomolar) \\
\hline 13 & Quercetin & $-8.34 \mathrm{kcal} / \mathrm{mol}$ & $766.90 \mathrm{nM}$ (nanomolar) \\
\hline I4 & Delphinidin & $-8.33 \mathrm{kcal} / \mathrm{mol}$ & $783.60 \mathrm{nM}$ (nanomolar) \\
\hline 15 & Formononetin & $-8.28 \mathrm{kcal} / \mathrm{mol}$ & $850.36 \mathrm{nM}$ (nanomolar) \\
\hline 16 & Naringenin & $-8.26 \mathrm{kcal} / \mathrm{mol}$ & 880.3I nM (nanomolar) \\
\hline 17 & Epicatechin & $-8.24 \mathrm{kcal} / \mathrm{mol}$ & 907.I5 nM (nanomolar) \\
\hline I8 & Apigenin & $-8.10 \mathrm{kcal} / \mathrm{mol}$ & I.I6 uM (micromolar) \\
\hline 19 & Phloretin & $-8.02 \mathrm{kcal} / \mathrm{mol}$ & I.33 uM (micromolar) \\
\hline 20 & Gossypetin & $-8.0 \mathrm{I} \mathrm{kcal} / \mathrm{mol}$ & I.34 uM (micromolar) \\
\hline 21 & Biochanin A & - $7.99 \mathrm{kcal} / \mathrm{mol}$ & I.40 uM (micromolar) \\
\hline 22 & Genistein & - $7.9 \mathrm{I} \mathrm{kcal} / \mathrm{mol}$ & I.60 uM (micromolar) \\
\hline 23 & Morin & $-7.88 \mathrm{kcal} / \mathrm{mol}$ & I.68 uM (micromolar) \\
\hline 24 & Kaempferol & $-7.88 \mathrm{kcal} / \mathrm{mol}$ & I.69 uM (micromolar) \\
\hline 25 & Isoformononetin & $-7.83 \mathrm{kcal} / \mathrm{mol}$ & I.8I uM (micromolar) \\
\hline 26 & Daidzein & $-7.83 \mathrm{kcal} / \mathrm{mol}$ & I.82 uM (micromolar) \\
\hline 27 & Esculin & $-7.8 \mathrm{I} \mathrm{kcal} / \mathrm{mol}$ & I. $.88 \mathrm{uM}$ (micromolar) \\
\hline 28 & Glycitein & $-7.78 \mathrm{kcal} / \mathrm{mol}$ & I.98 uM (micromolar) \\
\hline 29 & Prunetin & $-7.64 \mathrm{kcal} / \mathrm{mol}$ & 2.5 I uM (micromolar) \\
\hline 30 & Daidzin & $-5.14 \mathrm{kcal} / \mathrm{mol}$ & I72.I I uM (micromolar) \\
\hline
\end{tabular}




\begin{tabular}{|c|c|c|c|}
\hline $3 \mathrm{I}$ & Sissotrin & $-5.05 \mathrm{kcal} / \mathrm{mol}$ & I98.63 uM (micromolar) \\
\hline 32 & Genistin & $-4.85 \mathrm{kcal} / \mathrm{mol}$ & $279.37 \mathrm{uM}$ (micromolar) \\
\hline 33 & Ononin & $-4.35 \mathrm{kcal} / \mathrm{mol}$ & $651.65 \mathrm{uM}$ (micromolar) \\
\hline
\end{tabular}

The molecular docking data on the ID: 6COX protein in Table I shows the compounds with the lowest docking value, namely the Ononin with a $\Delta \mathrm{G}$ value of $-4.35 \mathrm{kcal} / \mathrm{mol}$ and IC of $65 \mathrm{I} .65 \mathrm{uM}$. While the results of the best docking of the flavonoid compound were occupied by the Epicatechin-3-OGallate compound with $\Delta \mathrm{G}=-9.31 \mathrm{kcal} / \mathrm{mol}$ and IC of I $49.65 \mathrm{nM}$ (nanomolar), then followed by the Gallocatechin compound $\Delta \mathrm{G}=-8.97 \mathrm{kcal} / \mathrm{mol}$ and IC $=266.19 \mathrm{nM}$ (nanomolar), with Tamarixetin $\Delta \mathrm{G}$ $=-8.83 \mathrm{kcal} / \mathrm{mol}$ and $\mathrm{IC}=335.7 \mathrm{I} \mathrm{nM}$ (nanomolar).

The data of free bond energy $(\Delta \mathrm{G})$ shows that the most stable compound is the Epicatechin-3-OGallate compound, followed by the Gallocatechin and Tamarixetin compounds. The stability of the compound can be seen from its low binding energy. The lower the binding energy and the stronger noncovalent interactions may affect more spontaneous reactions between ligands and proteins (Suhadi, Rizarullah, and Feriyani 2019). Epicatechin-3-OGallate can be a candidate for COX-2 inhibitor and its strength is much higher when compared to Gallocatechin and Tamarixetin.

As shown in the IC data, the smallest value is owned by the Epicatechin-3-O-Gallate compound, followed by the Gallocatechin and Tamarixetin compounds. The smaller the constant inhibition value was, the more stable the ligand-receptor complex affects the high ability compound is as inhibitor COX-2. Based on this study, the Epicatechin-3-O-Gallate compound has the highest affinity. It has a greater inhibitory power to bind to protein, resulting in the drug's biological activity may form of more potent COX-2 inhibition. In other words, the Epicatechin-3-O-Gallate compound has a more significant potential to inhibit COX-2 compared to other compounds. The constant inhibition value can also be used to reference or compare in conducting the in vitro (IC50).

In this study, the Epicatechin-3-O-Gallate compound had the most significant potential in inhibiting COX-2. The finding of this research follows Al-Sayed and Abdel-Daim's (2018) research, which also showed the anti-inflammatory activity of the Epicatechin Gallate compound in mice induced by carrageenan in vivo and there was inhibition of high concentrations of the anti-inflammatory mediator PGE2. PGE2 are major pro-inflammatory induced by COX-2 than COX-I.
The Gallocatechin compound is in the second position based on the docking score ranking after the Gallocatechin compound, which may have antiinflammatory COX-2 inhibitor potential. This prediction is corroborated by research from Gürbüz et al. (2019), which states that the Epicatechin Gallate compound has anti-inflammatory activity and an inhibitor by reducing iNOS and COX-2 levels in RAW 264.7 cells induced by LPS + IFN$\gamma$ through RT-PCR screening.

Tamarixetin is the third compound that has the highest docking value after Epicatechin-3-O-Gallate and Gallocatechin. The docking value shows that the Tamarixetin compound has the potential as a selective COX-2 enzyme inhibitor. The prediction of Tamarixetin as a COX-2 inhibitor is supported by in vitro experimental studies from Park et al. (2018), where Tamarixetin compounds have antiinflammatory activity by inhibiting the phosphorylation of JNKI, p38, and Akt, and inhibiting COX-2 expression in Bone Marrow Dendritic Cells (BMDCs) stimulated by LPS.

Based on the research above, it has been shown that the three compounds with the highest docking value (Epicatechin-3-O-Gallate, Gallocatechin and Tamarixetin) not only have the potential to have anti-inflammatory activity by in silico docking but some of them have been proven experimentally to have anti-inflammatory activity particularly specific as a COX-2 inhibitor.

\section{Amino Acid Residues Interaction}

Observation of amino acid residues from the interaction of the flavonoid compound with the target protein aims to identify the interactions that occur and are thought to contribute to the emergence of pharmacological effects such as COX-2 inhibitors by the flavonoid compound. These bond interactions are hydrogen bonds, hydrophobic interactions, Van der Waals interactions, electrostatic interactions, and halogens (Oo et al., 2016). Hydrogen bonds play a major role in the inhibition of molecular protein complexes. On the other hand, hydrogen bonds also make protein-ligand complexes stable and produce biological activity (Ya'u Ibrahim et al. 2020). Hydrogen bonds are the strongest of the noncovalent bonds but weaker than ionic or covalent bonds. Therefore, the amino acid with the most hydrogen bonds is possible to be the most significant contributor in producing the best activity. 
Table 2 Amino acid residue interaction formed hydrogen bond

\begin{tabular}{|c|c|c|}
\hline No & Compounds & Hydrogen Bond \\
\hline $\bar{I}$ & 558 & 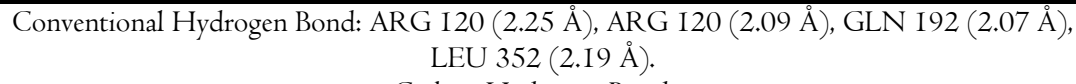 \\
\hline 2 & Celecoxib & 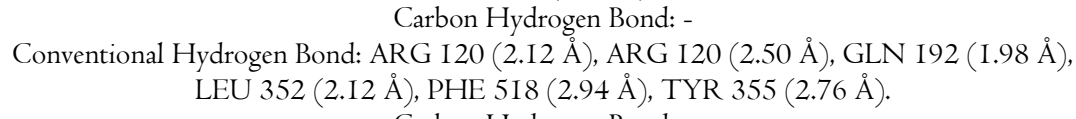 \\
\hline 3 & $\begin{array}{l}\text { Epicatechin-3-O- } \\
\quad \text { Gallate }\end{array}$ & $\begin{array}{l}\text { Carbon Hydrogen Bond: - } \\
\text { Conventional Hydrogen Bond: ARG I20 (2.09 }) \text {, ARG I20 (2.85 }) \text {, GLN I92 (2.I4 } \AA) \text {, } \\
\text { PHE 5I8 }(2.55 \AA) \text {, ARG 5I3 }(2.22 \AA) \text {. } \\
\text { Carbon Hydrogen Bond: SER } 353(2.80 \AA) .\end{array}$ \\
\hline 4 & Gallocatechin & 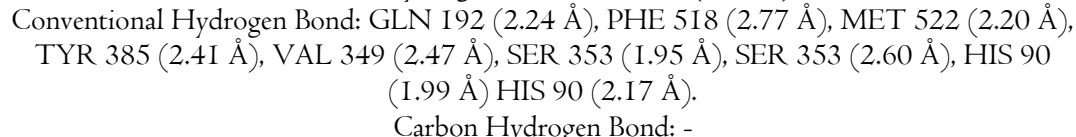 \\
\hline 5 & Tamarixetin & 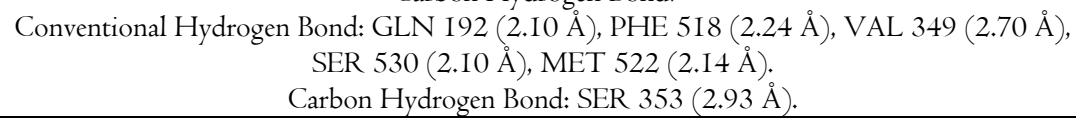 \\
\hline
\end{tabular}

Actually, there are 17 types of amino acids form hydrogen bonds derived from the interaction of 33 ligands and the ID: 6COX protein, but on Table 2 above, we show amino acid interaction of 5 ligands with the high docking score. The amino acid interaction and 3D visualization of 5 ligands already showed on Fig.2 ligand native SC-558, Fig.3 Celecoxib, Fig.4 Epicatechin-3-O-gallate, Fig.5 Gallocatechin and Fig.6 Tamarixetin.

In this study, the TYR 385 formed 23 interaction is the amino acid that most contributes to forming hydrogen bonds between ligands and protein ID: 6COX. This research supported by Yanuar, Setiajid, and Hayun (20I4) on docking and simulating the molecular dynamics of the cyclooxygenase-2 complex with several Kuinazolinone derivative compounds form hydrogen bonds with a percentage of occupancy above $90 \%$ (very strong hydrogen bonds) on the TYR 385 residue. Whereas in Basumatary et al. (2018) research related to compound 2, 3-Dimethylmaleic Anhydride forms a hydrogen bond interaction with TYR 385 on the protein A chain. The two above research were carried out on the COX-2 protein with the same code, namely the protein ID: 6COX.

The SER 353 amino acid residue formed 29 hydrogen bonding interactions in this study. In a study by Meenambiga, Rajagopal, and Durga (2015) using the ID: 6COX protein, it was stated that one of the SER 353 residues was in the active site area of the COX-2 enzyme. The same research from Yanuar et al. (20I4) above found that SER 353 residues also had an occupancy percentage above $90 \%$ (very strong hydrogen bonds).

This study shows that SER 530 amino acid residues were also found to make 18 hydrogen bonding interactions. SER 530 residue also formed hydrogen bonds in the research of Basumatary et al. (2018) regarding the interaction of Compound 2, 3Dimethylmaleic Anhydride with molecular docking and molecular dynamics studies using protein ID: 6COX.

The amino acid residues of GLN 192 formed 18 hydrogen bonding interactions in the 15 compounds with the highest docking ranking. In another study, GLN 192 residues were also shown to form hydrogen bonds by docking on the derivative 2,4Diaryl-5-4H-imidazolone to design antiinflammatory activity with the protein ID: 6COX (El-Araby et al. 20I2).

Based on this research, the amino acid residues of ARG I20 formed many hydrogen bond interactions in the three compounds with the top docking (SC558, Celecoxib, and Epicatechin-3-O-Gallate compounds). In the research of Alagumuthu, Sathiyanarayanan, and Arumugam (2015), ARG I20 residues played a role in forming inhibitory biological activity of COX-2, related to their research in the form of COX-2 (ID: 6COX) inhibitory activity by Isoquinolin derivative compounds.

In this study amino acid of SER 353, TYR 385, SER 530, GLN 192, and ARG I20 has contributed to the formatted hydrogen bonds, those 5 residues are also found in other studies. This research shows that the ligand in the molecule docking process on the target protein is in the right place on the active site. This is evidenced by the similarity of the hydrogen bonding interactions of the five amino acid residues above. 


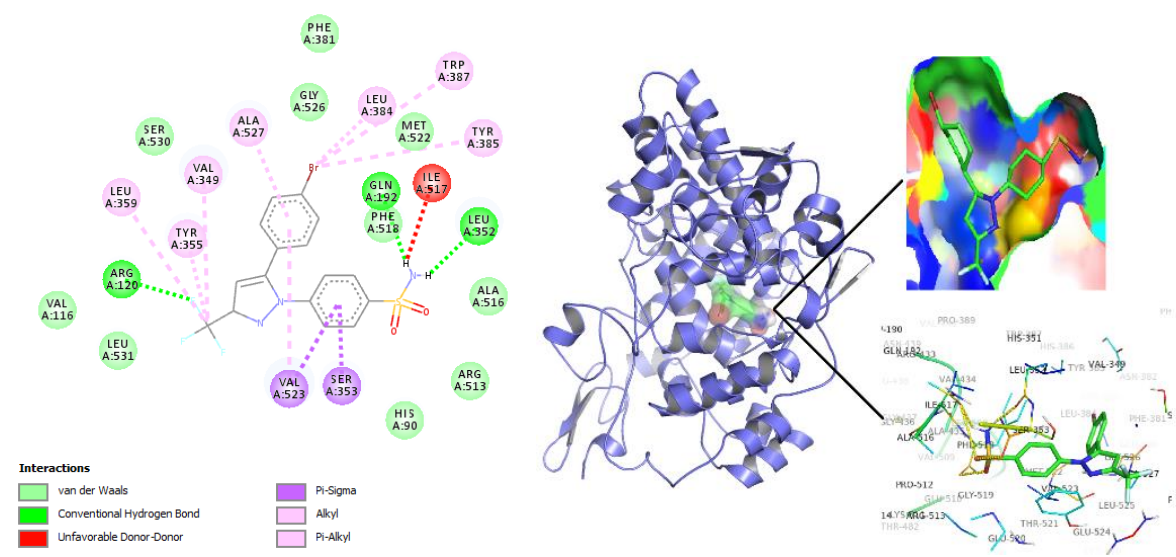

Figure 2 Molecular docking visualization of ligand native SC-558: (a) 2D diagram of hydrogen bond and other intermolecular interaction between ligand and A chains protein; (b) ligand native on binding pocket protein ID: $6 \mathrm{COX}$

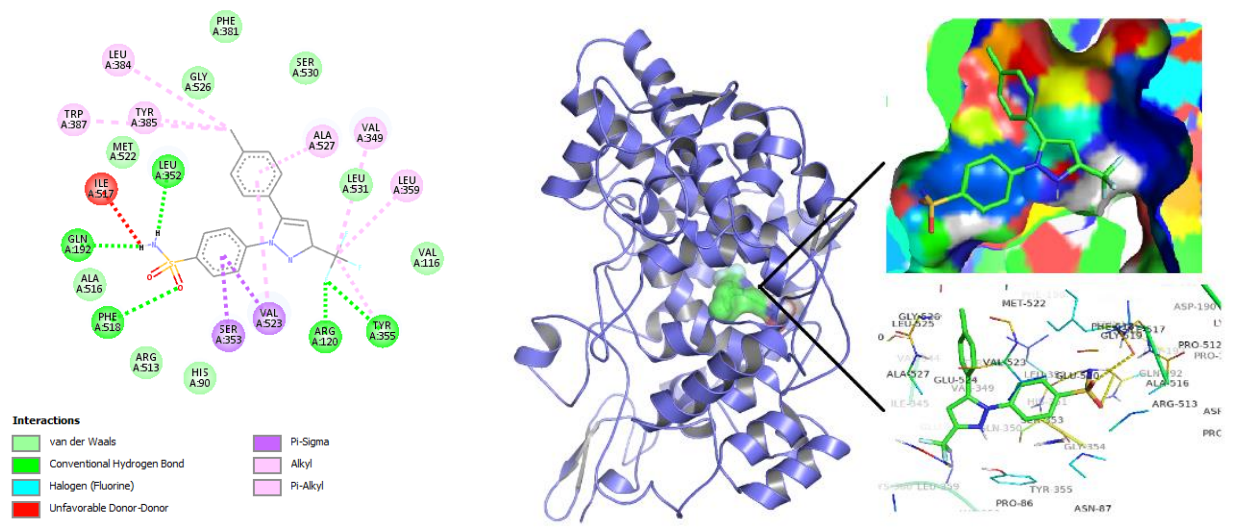

Figure 3 Molecular docking visualization of celecoxib (a) 2D diagram of hydrogen bond and other intermolecular interaction between Celecoxib and A chains protein; (b) Celecoxib on binding pocket protein ID: 6COX
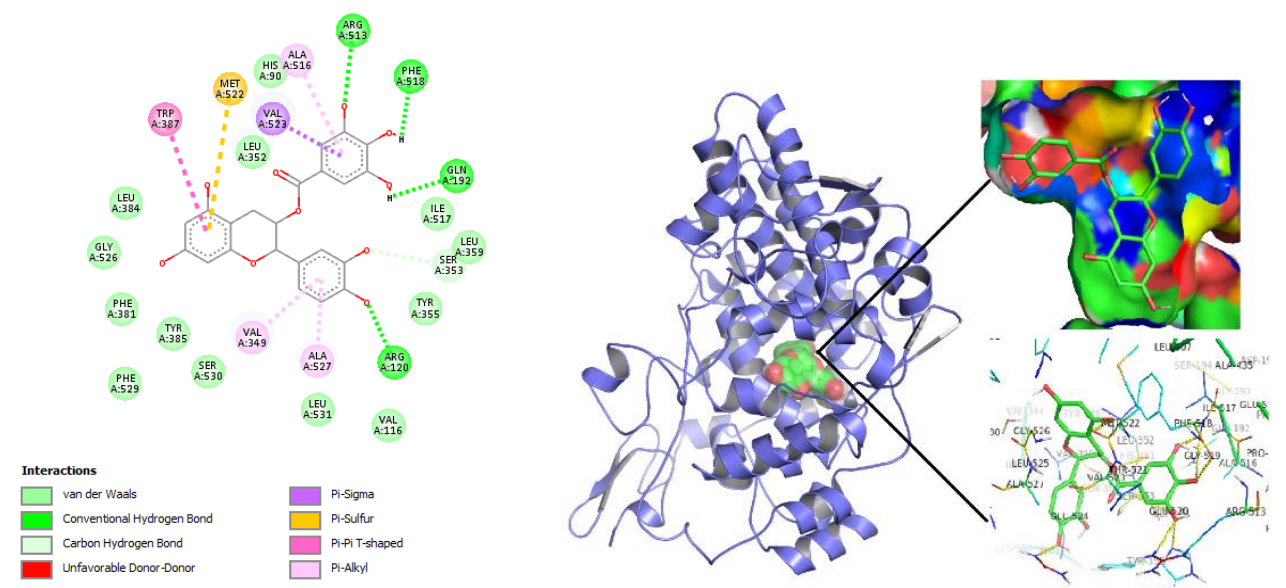

Figure 4 Molecular docking visualization of Epicatechin-3-O-gallate: (a) 2D diagram of hydrogen bond and other intermolecular interaction between Epicatechin-3-O-gallate and A chains protein; (b) Epicatechin-3-Ogallate on binding pocket protein ID: $6 \mathrm{COX}$ 


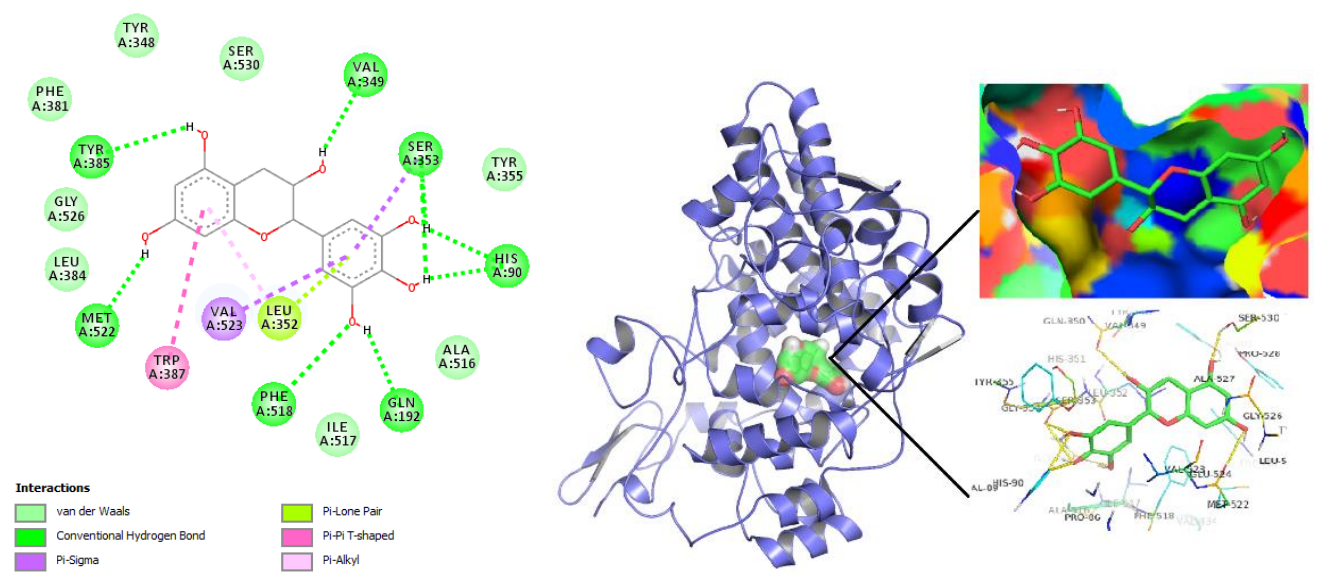

Figure 5 Molecular docking visualization of Gallocatechin: (a) 2D diagram of hydrogen bond and other intermolecular interaction between Gallocatechin and A chains protein; (b) Gallocatechin on binding pocket

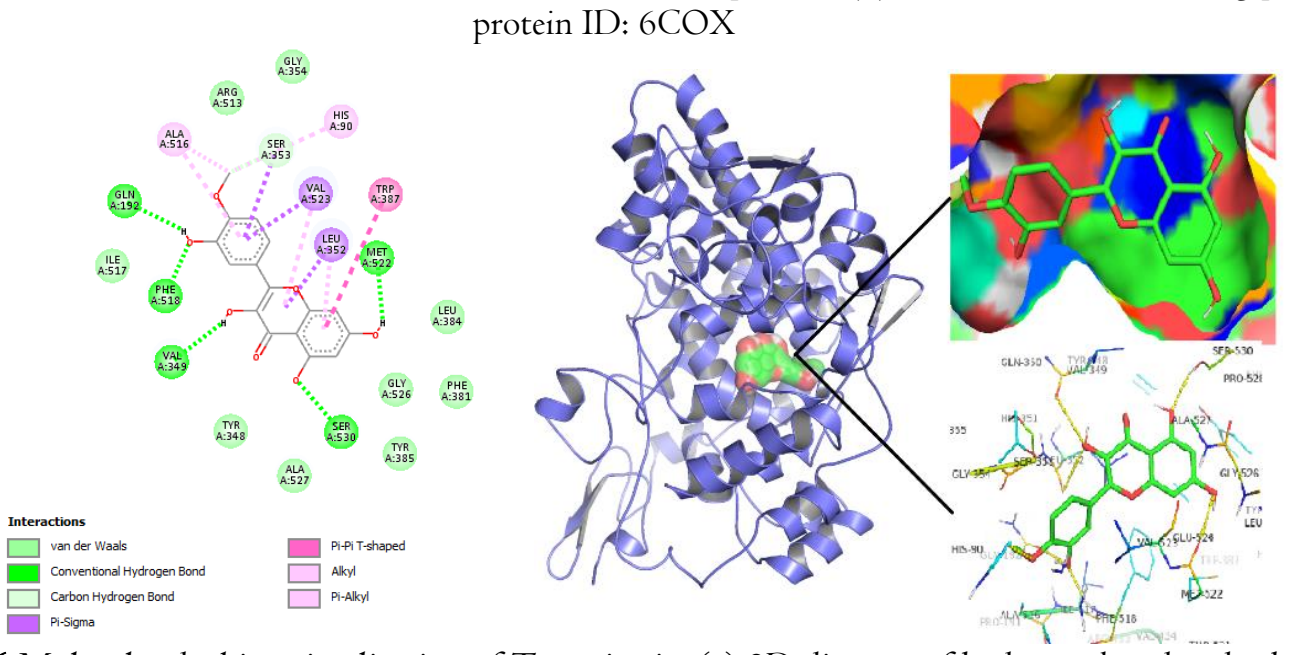

Figure 6 Molecular docking visualization of Tamarixetin: (a) 2D diagram of hydrogen bond and other intermolecular interaction between Tamarixetin and A chains protein; (b) Tamarixetin on binding pocket protein ID: $6 \mathrm{COX}$

\section{ADMET Prediction}

The discovery of new drugs is not only seen by the strength of the ligand binding on the target protein. However, it is also evaluated in terms of pharmacokinetics and toxicity to determine the degree of effectiveness and therapeutic efficacy. Pharmacokinetic processes or drug travel in the body start from Absorption, Distribution, Metabolism, and Excretion (ADME). Predicting Small-Molecule Pharmacokinetic Properties Using Graph-Based
Signatures or pkCSM is a site that provides predictions of ADMET properties in new chemical compounds with a high degree of accuracy. ADMET screened all flavonoid compounds through the pkCSM web server, and ADMET predictions were displayed from the three best dockings of flavonoid compounds include Epicatechin-3-O-gallate, Gallocatechin, and Tamarixetin.

Table 3 Predicted pcKSM of flavonoid compounds

\begin{tabular}{|c|c|c|c|c|c|}
\hline \multirow[b]{2}{*}{ Models } & \multirow[b]{2}{*}{ unit } & \multicolumn{3}{|c|}{ Compounds } & \multirow{2}{*}{$\begin{array}{c}\text { Parameters (D. E. V } \\
\text { Pires, Blundell, and } \\
\text { Ascher 20I5) }\end{array}$} \\
\hline & & $\begin{array}{l}\text { Epicatechin- } \\
\text { 3-O-gallate }\end{array}$ & Gallocatechin & Tamarixetin & \\
\hline \multicolumn{6}{|l|}{ Absorption } \\
\hline Caco2 permeability & $\begin{array}{c}\text { Numeric (log } \\
\text { Papp in } \mathrm{I}^{-6} \\
\mathrm{~cm} / \mathrm{s} \text { ) }\end{array}$ & $-\mathrm{I}, 807$ & -0.597 & -0.507 & High permeability $<0.90$ \\
\hline $\begin{array}{l}\text { Intestinal absorption } \\
\text { (human) }\end{array}$ & $\begin{array}{l}\text { Numeric (\% } \\
\text { Absorbed) }\end{array}$ & 63,139 & 58,153 & $72.7 \mathrm{I}$ & $\begin{array}{l}\text { Poorly absorbed if less } \\
\text { than } 30 \%\end{array}$ \\
\hline
\end{tabular}




\begin{tabular}{|c|c|c|c|c|c|}
\hline Skin Permeability & Numeric $(\log \mathrm{Kp})$ & $-2,735$ & $-2,735$ & $-2,735$ & $\begin{array}{l}\text { Low skin permeability if } \\
\qquad \log K_{p}>-2.5\end{array}$ \\
\hline \multicolumn{6}{|l|}{ Distribution } \\
\hline VDss (human) & $\begin{array}{l}\text { Numeric }(\log \\
\mathrm{L} / \mathrm{kg})\end{array}$ & 0.683 & 0.999 & -0.09 & $\begin{array}{c}\text { Low VDss if } \log \text { VDss }< \\
-0.15 \\
\text { High VDss if } \log \text { VDss } \\
>0.45\end{array}$ \\
\hline BBB permeability & Numeric (log BB) & $-\mathrm{I}, 992$ & -1.57 & $-\mathrm{I}, 294$ & $\begin{array}{l}\text { Good distribution to the } \\
\text { brain if } \log \mathrm{BB}>0.3 \\
\text { Bad distribution to the } \\
\text { brain if } \log \mathrm{BB}<-\mathrm{I}\end{array}$ \\
\hline CNS permeability & Numeric (log PS) & $-3,734$ & $-3,5 \mathrm{I} 4$ & $-3,246$ & $\begin{array}{c}\text { Can penetrate the CNS if } \\
\text { Log PS }>-2 \\
\text { Unable to penetrate the } \\
\text { CNS if Log PS }<-3\end{array}$ \\
\hline \multicolumn{6}{|l|}{ Metabolism } \\
\hline CYP2D6 substrate & $\begin{array}{l}\text { Categorical } \\
\text { (Yes/No) }\end{array}$ & No & No & No & \\
\hline CYP3A4 substrate & & Yes & No & No & \\
\hline CYPIA2 inhibitor & & No & No & Yes & \\
\hline CYP2CI9 inhibitor & & No & No & No & \\
\hline CYP2C9 inhibitor & & No & No & No & \\
\hline CYP2D6 inhibitor & & No & No & No & \\
\hline CYP3A4 inhibitor & & No & No & No & \\
\hline \multicolumn{6}{|l|}{ Excretion } \\
\hline Total Clearance & $\begin{array}{l}\text { Numeric (log } \\
\mathrm{ml} / \mathrm{min} / \mathrm{kg})\end{array}$ & -0.213 & 0.268 & 0.513 & \\
\hline Renal OCT2 substrate & $\begin{array}{l}\text { Categorical } \\
\text { (Yes/No) }\end{array}$ & No & No & No & \\
\hline \multicolumn{6}{|l|}{ Toxicity } \\
\hline AMES toxicity & $\begin{array}{l}\text { Categorical } \\
\text { (Yes/No) }\end{array}$ & No & No & No & \\
\hline hERG I inhibitor & & No & No & No & \\
\hline hERG II inhibitor & & Yes & No & No & \\
\hline Hepatotoxicity & & No & No & No & \\
\hline Skin Sensitisation & & No & No & No & \\
\hline T.Pyriformis toxicity & $\begin{array}{l}\text { Numeric (log } \\
\text { ug/L) }\end{array}$ & 0.285 & $0.3 \mathrm{II}$ & 0.355 & $\begin{array}{l}\text { Compound predicted } \\
\text { toxic if } \log >0.5 \mathrm{ug} / \mathrm{L}\end{array}$ \\
\hline Minnow toxicity & $\begin{array}{l}\text { Numeric (log } \\
\mathrm{mM})\end{array}$ & 5,906 & 5,068 & 3,478 & $\begin{array}{c}\text { Compound predicted } \\
\text { high acute toxic if Log } \\
<-0.3\end{array}$ \\
\hline
\end{tabular}

Epicatechin-3-O-gallate, Gallocatechin, and Tamarixetin have slightly low permeability to Caco2 permeability in the human intestinal mucosa. However, it is predicted to have good absorption of Intestinal human absorption, which means all compounds can absorb through small intestinal humans. On another side, those three flavonoid compounds have high skin permeability, so it is predicted that the preparations can be made in the topical formulation with the transdermal route.

Prediction in the distribution phase, it is possible that the three flavonoid compounds Epicatechin-3-Ogallate, Gallocatechin, and Tamarixetin can be distributed more in the network because all compounds have high VDss (human) (log $>0.45)$. However, the permeability to BBB \& CNS is insufficient (not suitable for targeting as drug candidates for BBB \& CNS, possibly because of their low lipophilicity).

Based on metabolism prediction, the three compounds, such as Epicatechin-3-O-gallate, Gallocatechin, and Tamarixetin do not inhibit the drug metabolism process carried out by cytochrome P450, and inhibit CYPIA2 does not have a major effect on the process of drug metabolism. The substrate prediction shows that three compounds can be appropriately metabolized by cytochrome $\mathrm{P} 450$ and are easily excreted.

Tamarixetin produced the highest rate of total clearance in the excretion compound prediction compared to Epicatechin-3-O-gallate and 
gallocatechin. These three compounds are also not a Renal OCT2 substrate, so it is predicted that they will not cause toxicity if they are made for oral drug delivery that is taken together with Renal OCT2 inhibitors.

Epicatechin-3-O-gallate, Gallocatechin, and Tamarixetin were predicted not to cause mutations in the predicted AMES and were not hepatotoxic. In the hERG inhibitor, only the Epicatechin-3-O-gallate compound is a possible hERG inhibitor (a side effect may create heart problems). The three compounds were also predicted to have toxicity to protozoa in the $T$. Pyriformis toxicity but low toxicity to the environment in the Minnow Toxicity.

\section{Conclusion and Recommendation}

Research on the flavonoid compounds on the ID: 6COX protein as a COX-2 inhibitor using the molecular docking obtained the best free bond energy $(\Delta \mathrm{G})$ as the results of the flavonoid compound, the high-rank value of $-9.3 \mathrm{I} \mathrm{kcal} / \mathrm{mol}$ were from the Epicatechin-3-O-Gallate, which have potential activity as COX-2 inhibitors and amino acid residues most playing role of this research is SER 353, TYR 385, SER 530, ARG I20, and GLN I92. In future research, we expect new prospective studies to demonstrate further Molecular Dynamic or QSAR using the best docking rank of flavonoids compound to evaluate bond strength and biological activity.

\section{References}

Abdillah, Muhammad Nur, Nefi Rofani Ilmah, and Andhika Bintang Mahardhika. 2017. "Penambatan Molekuler Senyawa Polifenolat Terhadap Enzim Reverse Transcriptase Sebagai Senyawa Antiretroviral (HIV-I).” JSTFI Indonesian Journal of Pharmaceutical Science and Technology 6(I):36-44.

Adelina, Rosa. 20I4. "Molecular Docking Studies of Annomuricin E and Muricapentocin on Antiproliferation Activity." Pp. 32-36 in Jurnal Ilmu Kefarmasian Indonesia. Vol. I2.

Al-Sayed, Eman, and Mohamed M. Abdel-Daim. 2018. "Analgesic and Anti-Inflammatory Activities of Epicatechin Gallate from Bauhinia Hookeri." Drug Development Research 79(4):157-64. doi: https://doi.org/I0.I002/ddr.2I430.

Alagumuthu, Manikandan, Kulathu Iyer Sathiyanarayanan, and Sivakumar Arumugam. 2015. "Molecular Docking, Design, Synthesis, in Vitro Antioxidant and AntiInflammatory Evaluations of New Isoquinoline Derivatives." International Journal of Pharmacy and Pharmaceutical Sciences 7(12):200-208.
Anand, Vijaya, Manikandan, Vijaya Kumar, Sampath Kumar, Pushpa, and Agaath Hedina. 2016. "Phytopharmacological Overview of Psidium Guajava Linn." Pharmacognosy Journal $8(4): 3$ I4-20. doi: https://doi.org/I0.5530/pj.2016.4.3.

Barbalho, Sandra M., Flávia M. V Farinazzi-machado, Ricardo De Alvares Goulart, Anna Cláudia, Saad Brunnati, and Alda Maria Machado. 2012. "Psidium Guajava (Guava): A Plant of Multipurpose Medicinal Applications." Medicinal \& Aromatic Plants 0I(04):I-6. doi: $\quad$ https://doi.org/I0.4172/21670412.1000104.

Basumatary, Panchamita, Manas Das, Pranjan Barman, and Manisha Choudhury. 2018. "Molecular Docking Study of 2, 3-Dimethylmaleic Anhydride (3, 4-Dimethyl-2, 5-Furandione) as Anti-Inflammatory Agent." Trends in Bioinformatics II(2):56-63. doi: https://doi.org/I0.3923/tb.20I8.56.63.

Chen, Linlin, Huidan Deng, Hengmin Cui, Jing Fang, Zhicai Zuo, Junliang Deng, Yinglun Li, Xun Wang, and Ling Zhao. 2018. "Inflammatory Responses and Inflammation-Associated Diseases in Organs." Oncotarget 9(6):7204I8.

doi: https://doi.org/IO.I8632/oncotarget.2320 8.

Choi, Soo-Youn, Joon-Ho Hwang, Soo-Young Park, Yeong-Jun Jin, Hee-Chul Ko, Sang-Wook Moon, and Se-Jae Kim. 2008. "Fermented Guava Leaf Extract Inhibits LPS- Induced COX-2 and INOS Expression in Mouse Macrophage Cells by Inhibition of Transcription Factor NF-KB." Phytotherapy Research 22(4):I030-I034. doi: https://doi.org/I0.1002/ptr.24I9.

Curtis, Elizabeth, Nicholas Fuggle, Sarah Shaw, Laura Spooner, Georgia Ntani, Camille Parsons, Nadia Corp, Germain Honvo, Janis Baird, Stefania Maggi, Elaine Dennison, Olivier Bruyère, Jean Yves Reginster, and Cyrus Cooper. 2019. "Safety of Cyclooxygenase-2 Inhibitors in Osteoarthritis: Outcomes of a Systematic Review and Meta-Analysis." Drugs and Aging 36(I):25-44. doi: https://doi.org/I0.1007/s40266-01900664-x.

D'mello, Priscilla, Manoj Kumar Gadhwal, Urmila Joshi, and Preetam Shetgiri. 20I I. "Modeling of COX-2 Inhibitory Activity of Flavonoids." International Journal of Pharmacy and Pharmaceutical Sciences 3(4):33-40. 
Desai, Shreena J., Ben Prickril, and Avraham Rasooly. 2018. "Mechanisms of Phytonutrient Modulation of Cyclooxygenase-2 (COX-2) and Inflammation Related to Cancer." Nutrition and Cancer 70(3):350-75. doi: https://doi.org/I0.I080/0I63558I.20I8. I44609I.

El-Araby, Moustafa, Abdelsattar Omar, Hassanein H. Hassanein, Abdel Ghany H. El-Helby, and Asharf A. Abdel-Rahman. 2012. "Design, Synthesis and in Vivo Anti-Inflammatory Activities of 2,4-Diaryl-5-4H-Imidazolone Derivatives." Molecules I7(I0):12262-75. doi:

https://doi.org/I0.3390/molecules I7IOI2 262.

Fuhrmann, Jan, Alexander Rurainski, Hans-Peter Lenhof, and Dirk Neumann. 20I0. "A New Lamarckian Genetic Algorithm for Flexible Ligand-Receptor Docking." Journal of Computational Chemistry 3 I(9):I9I I-I9I8. doi: https://doi.org/I0.1002/jcc.2I478.

Fujita, Hiroki, Masafumi Kakei, Hiromi Fujishima, Tsukasa Morii, Yuichiro Yamada, Zhonghua Qi, and Matthew D. Breyer. 2007. "Effect of Selective Cyclooxygenase-2 (COX-2) Inhibitor Treatment on Glucose-Stimulated Insulin Secretion in C57BL/6 Mice." Biochemical and Biophysical Research Communications 363(I):37-43. doi: I0.1016/j.bbrc.2007.08.090.

Guan, Pei Pei, and Pu Wang. 2019. "Integrated Communications between Cyclooxygenase-2 and Alzheimer's Disease." The FASEB Journal 33(I):I-2I. doi: https://doi.org/I0.1096/fj.20I800355RR RR.

Gürbüz, Perihan, Şengül Dilem Doğan, Gizem Nur Çelik, Hatice Bekci, Ahmet Cumaoğlu, Miyase Gözde Gündüz, and Mehmet Yavuz Paksoy. 2019. "Bioactivity-Guided Isolation of Anti-Inflammatory Principles from Cistus Parviflorus Lam." Records of Natural Products I3(3):226-35. doi: https://doi.org/I0.25135/RNP.I06.I8.09 .883 .

Habtemariam, Solomon. 2019. The Chemical and Pharmacological Basis of Guava (Psidium Guajava L.) as Potential Therapy for Type 2 Diabetes and Associated Diseases. Elsevier Ltd.

Harisna, Azza Hanif, Rizky Nurdiansyah, Putri Hawa Syaifie, Dwi Wahyu Nugroho, Kurniawan Eko Saputro, Firdayani, Chandra Dwi Prakoso, Nurul Taufiqu Rochman,
Nurwenda Novan Maulana, Alfian Noviyanto, and Etik Mardliyati. 202I. "In Silico Investigation of Potential Inhibitors to Main Protease and Spike Protein of SARSCoV-2 in Propolis." Biochemistry and Biophysics Reports 26:I-I3. doi: https://doi.org/I0.10I6/j.bbrep.2021.100 969.

Hussein, R. K., and H. M. Elkhair. 202I. "Molecular Docking Identification for the Efficacy of Some Zinc Complexes with Chloroquine and Hydroxychloroquine against Main Protease of COVID-19." Journal of Molecular Structure I23I:I-9. doi: https://doi.org/I0.I0I6/j.molstruc.202I.I 29979.

Iheagwam, Franklyn Nonso, Olubanke Olujoke Ogunlana, Oluseyi Ebenezer Ogunlana, Itunuoluwa Isewon, and Jelili Oyelade. 2019. "Potential Anti-Cancer Flavonoids Isolated from Caesalpinia Bonduc Young Twigs and Leaves: Molecular Docking and in Silico Studies." Bioinformatics and Biology Insights I3:I-I6. doi: https://doi.org/IO.I I77/I I779322I882I 371.

Jiang, Lirong, Junyu Lu, Yue Qin, Weirong Jiang, and Yanping Wang. 2020. "Antitumor Effect of Guava Leaves on Lung Cancer: A Network Pharmacology Study." Arabian Journal of Chemistry. doi: https://doi.org/I0.IOI6/j.arabjc.2020.09.0 IO.

Kartasasmita, Rahmana Emran, Rina Anugrah, and Daryono Hadi Tjahjono. 2015. "Kajian Docking Dan Prediksi Beberapa Aspek Farmakokinetika Desain Molekul Turunan Kuinin Sebagai Upaya Menemukan Kandidat Senyawa Antimalaria Yang Baru." Kartika Jurnal Ilmiah Farmasi 3(I):6-13. doi: https://doi.org/I0.26874/kjif.v3iI.I3.

Kelutur, Faruk Jayanto, Resmi Mustarichie, and Abdul Kakhar Umar. 2020. "Virtual Screening Kandungan Senyawa Kipas Laut (Gorgonia Mariae) Sebagai Anti-Asma." ALCHEMY Jurnal Penelitian Kimia I6(2):199-210. doi: https://doi.org/I0.2096I/alchemy.I6.2.39 96.199-210.

Meenambiga, Setti Sudharsan, Kalyanaraman Rajagopal, and R. Durga. 2015. "In Silico Docking Studies on the Components of Inonotus Sp., a Medicinal Mushroom against Cyclooxygenase-2 Enzyme." Asian Journal of Pharmaceutical and Clinical Research $8(3): 142-45$. 
Nisha, Chaluveelaveedu Murleedharan, Ashwini Kumar, Prateek Nair, Nityasha Gupta, Chitrangda Silakari, Timir Tripathi, and Awanish Kumar. 20I6. "Molecular Docking and In Silico ADMET Study Reveals Acylguanidine $7 \mathrm{a}$ as a Potential Inhibitor of BSecretase." Advances in Bioinformatics 20I6:I-6. doi: https://doi.org/I0.II55/2016/9258578.

Nurtamin, Tomy, I. Putu Sudayasa, and Tien. 2018. "In Vitro Anti-Inflammatory Activities of Ethanolic Extract Elephantopus Scaber Leaves." Jurnal Kedokteran Dan Kesehatan Indonesia $9(\mathrm{I})$ :46-52. doi: https://doi.org/I0.20885/JKKI.Vol9.Iss I. art9.

Oo, Adrian, Pouya Hassandarvish, Sek Peng Chin, Vannajan Sanghiran Lee, Sazaly Abu Bakar, and Keivan Zandi. 2016. "In Silico Study on Anti-Chikungunya Virus Activity of Hesperetin." PeerJ (I0):I-23. doi: https://doi.org/10.7717/peerj.2602.

Park, Hee Jo, Seung Jun Lee, Joon Cho, Amal Gharbi, Hee Dong Han, Tae Heung Kang, Yangmee Kim, Yeongjoon Lee, Won Sun Park, In Duk Jung, and Yeong Min Park. 2018. "Tamarixetin Exhibits Anti-Inflammatory Activity and Prevents Bacterial Sepsis by Increasing IL-IO Production." Journal of Natural Products 8I(6):1435-43. doi: https://doi.org/I0.102I/acs.jnatprod.8b00 I55.

Pires, Douglas E. V., Tom L. Blundell, and David B. Ascher. 2015. "PkCSM: Predicting SmallMolecule Pharmacokinetic and Toxicity Properties Using Graph-Based Signatures." Journal of Medicinal Chemistry 58(9):406672. doi: https://doi.org/I0.I02I/acs.jmedchem.5b0 0104.

Pires, Douglas E. V, Tom L. Blundell, and David B. Ascher. 2015. "PkCSM: Predicting SmallMolecule Pharmacokinetic Properties Using Graph-Based Signatures (Theory- How to Enterpret PkCSM Result)." PKCSM 5.

Pranowo, Harno Dwi. 2009. "Peran Kimia Komputasi Dalam Desain Molekul Obat.” Pidato Pengukuhan JabatanGuru Besar Pada Fakultas Matematika Dan Ilmu Pengetahuan Alam Universitas Gadjah Mada.

Ricciotti, Emanuela, and Garret A. Fitzgerald. 201 I. "Prostaglandins and Inflammation." Arteriosclerosis, Thrombosis, and Vascular Biology 3I(5):986-I000. doi:
https://doi.org/IO.II6I/ATVBAHA.IIO. 207449.

Roy, Kunal, Supratik Kar, and Rudra Narayan Das. 2015. Understanding the Basics of QSAR for Applications in Pharmaceutical Sciences and Risk Assessment.

Satyanarayana, Sadam D. V., M. S. R. Krishna, Pindi Pavan Kumar, and Sirisha Jeereddy. 2018. "In Silico Structural Homology Modeling of Nif A Protein of Rhizobial Strains in Selective Legume Plants." Journal of Genetic Engineering and Biotechnology I6(2):73I37. https://doi.org/I0.I016/j.jgeb.2018.06.00 6.

Sen, Shib Sankar, V. Sukumaran, Sib Sankar Giri, and Se Chang Park. 20I5. "Flavonoid Fraction of Guava Leaf Extract Attenuates Lipopolysaccharide-Induced Inflammatory Response via Blocking of NF-KB Signalling Pathway in Labeo Rohita Macrophages." Fish and Shellfish Immunology 47(I):85-92. doi: https://doi.org/I0.I0I6/j.fsi.2015.08.03I.

Sohilait, Mario Rowan, Harno Dwi Pranowo, and Winarto Haryadi. 2017. "Molecular Docking Analysis of Curcumin Analogues with COX2." Bioinformation I3(II):356-59. doi: https://doi.org/I0.6026/9732063001335 6

Suhadi, Andrio, Rizarullah Rizarullah, and Feriyani Feriyani. 2019. "Simulasi Docking Senyawa Aktif Daun Binahong Sebagai Inhibitor Enzyme Aldose Reductase." Sel Jurnal Penelitian Kesehatan 6(2):55-65. doi: https://doi.org/10.22435/sel.v6i2.165I.

Thome, Angela Librianty, I. Ketut Sudiana, and Abu Bakar. 2019. "Psidium Guajava Leaves Compound As Anti-Inflammation: Systematic Review." Jurnal Natural I9(3):69-7I.

doi: https://doi.org/I0.248I5/jn.vI9i3.I3829.

Wati, Widia, Gunawan Pamudji Widodo, and Rina Herowati. 2020. "Prediction of Pharmacokinetics Parameter and Molecular Docking Study of Antidiabetic Compounds from Syzygium Polyanthum and Syzygium Cumini." Jurnal Kimia Sains Dan Aplikasi 23(6):189-95.

doi: https://doi.org/IO.I47I0/jksa.23.6.189195.

Ya'u Ibrahim, Zakari, Adamu Uzairu, Gideon Shallangwa, and Stephen Abechi. 2020. "Molecular Docking Studies, Drug-Likeness and in-Silico ADMET Prediction of Some Novel $\beta$-Amino Alcohol Grafted I,4,5- 
Trisubstituted 1,2,3-Triazoles Derivatives as Elevators of P53 Protein Levels." Scientific African I0:I-8. doi: https://doi.org/I0.1016/j.sciaf.2020.e005 70 .

Yanuar, Arry, Muhammad Aditya Setiajid, and Hayun. 20I4. "Analisis Penambatan Dan Simulasi Dinamika Molekular Komplex Siklooksigesinenase-2 Dengan Beberapa Senyawa Turunan Kuinazolinon.” Jurnal Farmasi Indonesia 7( I):50-59.

Yusuf, Muhammad, Ari Hardianto, Muchtaridi Muchtaridi, Rina F. Nuwarda, and Toto Subroto. 2018. Introduction of DockingBased Virtual Screening Workflow Using Desktop Personal Computer. Vols. I-3. Elsevier Ltd. 